\title{
Neurorestorative clinical application standards for the culture and quality control of olfactory ensheathing cells
}

This article was published in the following Dove Press journal:

Journal of Neurorestoratology

22 September 2017

Number of times this article has been viewed

\author{
Juan Xiao ${ }^{1,2}$ \\ Lin Chen ${ }^{3}$ \\ Gengsheng Mao' \\ Wenyong Gao ${ }^{1,2}$ \\ Ming $\mathrm{Lu}^{4}$ \\ Xijing $\mathrm{He}^{5}$ \\ Hongyun Huang ${ }^{1,2}$ \\ On behalf of the \\ Neurorestoratology \\ Professional Committee \\ of Chinese Medical \\ Doctors Association \\ (Chinese Association of \\ Neurorestoratology) \\ 'Institute of Neurorestoratology, \\ The General Hospital of Chinese \\ People's Armed Police Forces, \\ Beijing, People's Republic of China; \\ ${ }^{2}$ Cell Therapy Center, Beijing \\ Hongtianji Neuroscience Academy, \\ Beijing, People's Republic of China \\ ${ }^{3}$ Department of Neurosurgery, \\ Tsinghua University Yuquan Hospital, \\ Beijing, People's Republic of China; \\ ${ }^{4}$ Department of Neurosurgery, \\ I 63 Hospital of PLA (Second \\ Affiliated Hospital of Hunan Normal \\ University), Changsha, Hunan \\ Province, People's Republic of China; \\ ${ }^{5}$ Department of Orthopedics, Second \\ Affiliated Hospital of Xi'an Jiaotong \\ University, Xian, Shanxi Provine, \\ People's Republic of China
}

Correspondence: Hongyun Huang Institute of Neurorestoratology, General Hospital of Chinese People's Armed

Police Forces, 69 Yongding Road, Beijing

100039, People's Republic of China

Tel +86 I39 I0I I 6608

Email hongyunh@gmail.com

\begin{abstract}
Olfactory ensheathing cells (OECs) are a novel type of glial cell that can perform and promote many neurorestorative processes in vivo after transplant. To date, dozens of preclinical and clinical studies have confirmed that OECs have unique restoring effects in animal models and human subjects with neurological degeneration or damage, such as spinal cord injury, stroke, cerebral palsy, traumatic brain injury, and motor neuron disease (amyotrophic lateral sclerosis). To ensure the safety and effectiveness of clinical applications utilizing this type of cell, it is important to standardize cell-culture and quality-control processes. Based on a comprehensive review of published clinical studies, as well as existing methods of OEC culture and quality control currently utilized by hospitals and biomedical enterprises, the Chinese Association of Neurorestoratology has developed a set of standards for the culture and quality control of olfactory ensheathing cells for use in clinical applications. These guidelines include standardized training and management procedures for laboratory operators; standardized use and management of materials and equipment; standardized collection, culture, and proliferation of OECs obtained from fetal olfactory bulbs; standardized management for cell preservation, transport, and related safeguard measures; and the standardization of a clean environment, routine maintenance, and related tests and examinations. Our goal in publishing this set of standards is to promote the worldwide safety, effectiveness, and replicability of utilizing OECs obtained from fetal olfactory bulbs for neurorestorative clinical application.
\end{abstract}

Keywords: standardization, cell culture, quality control, olfactory ensheathing glial cells, neurorestorative clinical application, neurorestoratology, translational medicine

\section{Introduction}

Olfactory ensheathing cells (OECs) are a special type of glial cell with multiple characteristics. Similar to astrocytes and oligodendrocytes in the central nervous system and Schwann cells in the peripheral nervous system, OECs are able to induce olfactory axonal growth and guide the elongation of axons through the barrier between the peripheral and central nervous systems. OECs help in regenerating axonal nerve fibers go through glial scar tissue and promote remyelination. A large number of basic research and preclinical studies have confirmed that OECs have these unique central nervous system-neurorestorative effects in both animal models and human subjects. ${ }^{1-21}$

In order to ensure the safety, effectiveness, and replicability of OEC utilization for neurorestorative clinical applications, it is important to standardize cell-culture and quality-control processes. The Chinese Association of Neurorestoratology has developed the set of guidelines herein based on the guidelines for OEC preparation 
specified in current clinical studies, ${ }^{22-36}$ as well as the standards of OEC culture and quality control utilized by hospitals and biomedical enterprises. ${ }^{37-39}$ These guidelines include standardized training and management procedures for laboratory operators; standardized use and management of materials and equipment; standardized collection, culture, and proliferation of OECs obtained from fetal olfactory bulbs; standardized management for cell preservation, transport, and related safeguard measures; and the standardization of a clean environment, routine maintenance, and related tests and examinations.

\section{Standardized training and management for operators}

There should be at least one senior-level or higher professionallevel laboratory operator who is responsible for overseeing the cell-culture laboratory. Laboratory personnel should have a background in cell biology and receive systematic and professional training in cell-culture techniques and quality control for OECs. Basic standardized training items include knowledge learning, skill development, and familiarity with applicable rules and regulations. Training methods include system learning, practical training led by teachers, small seminars, symposia, and conferences. Training goals include mastering professional knowledge, cell-culture techniques, and quality-control processes for OECs obtained from fetal olfactory bulbs. A standardized management system should be established, including filling and keeping original work records and data, complying with the laboratory-maintenance standard operating procedures and current Good Manufacture Practice, and completing operating records.

\section{Standardized use and management of materials and equipment}

Cell-culture laboratories must be managed by a designated person who is responsible for equipment maintenance, regular calibration, and personnel training. The designee should maintain normal operational status within the laboratory and also establish and manage the equipment qualitycertification file records. The temperature should be kept at a consistent $37^{\circ} \mathrm{C}$ and the concentration of $\mathrm{CO}_{2}$ at $5 \%$. Objects should be kept for centrifugation in balance. Distilled water for the water-bath box should be changed and disinfected at least once a month. Inverted microscope lenses should be cleaned after using an oil mirror. The power should be turned off and the microscope s covered after each use. For superclean benches or biological safety cabinets, operation guidance for procedures should be strictly followed. After finishing each program or procedure, the designated person should determine whether all instruments are working appropriately. The power should be turned off for equipment not in use. Interventions should be written down systemically in the records.

\section{OEC-culture process Donor selection}

Female donors should have no history of infectious disease, such as HIV, hepatitis B, hepatitis C, or syphilis. Fetuses should be at least 12 gestational weeks old without brain malformations. The cell-procurement team should carry out informed-consent processes with potential donors and their families. After understanding and consenting to the donation, both the female donor and her family should sign the informed-consent form. The process must be approved by the relevant hospital ethics committees. ${ }^{37,40}$ Samples should be kept in a sterile bag and then placed in the freezer, with delivery to the laboratory as soon as possible.

\section{Cell-culture medium}

The cell-culture medium should consist of basal medium and serum substitute. Basal medium components include DF12 (DMEM:F12 1:1). Serum substitutes include transferrin, sodium selenate, biotin, insulin, glutamine, and bFGF. All materials must meet the quality standards of sterile, apathogenic microorganisms and endotoxins.

\section{Olfactory-bulb OEC-preparation steps}

1. Fetal remains should be disinfected using alcohol. To isolate the olfactory bulb, the fetal scalp must be cut, the skull removed, and the dura mater peeled.

2. Olfactory-bulb tissue should be placed on a sterile culture dish and transferred to the clean bench with DF12 rinse three times, removing the surface of any remaining blood.

3. Stripping tweezers should be used carefully to remove the soft membrane and blood vessels on the olfactory-bulb surface using a dissecting mirror. Operating procedures should be gentle to maintain the integrity of the tissue.

4. The olfactory bulb should be stripped onto a $35 \mathrm{~mm}$ glass plate, following DF12 culture-medium washing again, and adding 5-10 drops of DF12, with ophthalmic scissors repeatedly cutting. Attention should be focused on cutting the relatively large tissue block, but we should try to avoid further damage to the already-small-enough tissue block. Size of $0.5-1 \mathrm{~mm}^{3}$ is needed. 
5. Broken-down pieces of tissue should be taken into the centrifuge tube and then $5 \mathrm{~mL}$ of DF12 culture medium added, with gentle blowing back and forth by elbow suction tube to avoid physical damage to the cells.

6. Fetal tissue should undergo 1,000 revolution/minute centrifugation for 5 minutes. The supernatant should be removed, and then cleaning with DF12 repeated three times.

7. Serum (13\%) should be added, with gentle blowing back and forth by an elbow suction tube. The suspension should be suctioned into a $25 \mathrm{~cm}^{2}$ culture bottle.

8. Liquid ( $4 \mathrm{~mL})$ should be added per bottle in order to slow down rotation of the culture bottle and enable the tissue block to adhere evenly to the wall. Cells should be cultured in a $5 \% \mathrm{CO}_{2}$ incubator at $37^{\circ} \mathrm{C}$.

9. Based on cell growth, add half-volume change fluid using serum-free liquid for 3 days or so.

10. At 7-10 days later, if cells are growing well and cover the flask bottle, they can be used for clinical application or frozen and stored.

\section{OEC-cryopreservation and -recovery steps}

1. The culture broth should be aspirated and $2 \mathrm{~mL} \mathrm{DF} 12$ added to each flask. Add $4 \mathrm{~mL}$ DF12 to each flask and blow the cells from the side with a thick elbow pipette to avoid foaming.

2. After centrifugation at 1,000 revolutions/minute for 5 minutes, cells are corrected and then added to the cellcryopreservation solution.

3. Use a coarse elbow gently to blow and mix the cells into the cryopreservation tube. Mark the cell number, organization number, and make a good record of storage.

4. Carry out a cryopreservation program of $4{ }^{\circ} \mathrm{C}$, for 45 minutes, $-20^{\circ} \mathrm{C}$ for 1 hour, and $-80^{\circ} \mathrm{C}$ for 12 hours, and then place the sample into the liquid-nitrogen tank.

5. To resuscitate the sample for use in clinical applications, remove the frozen tube from the liquid-nitrogen tank and quickly immerse it into a hot $38.5^{\circ} \mathrm{C}$ water bath, continuously shaking to induce thawing as soon as possible. Use sterile gauze to dry the surface of any excess water, and then use a straw to suction out the cell suspension to a sterile $15 \mathrm{~mL}$ centrifuge tube. Then, add $10 \mathrm{~mL}$ DF12 culture liquid, blow on the cell suspension, and use the centrifuge for 5 minutes (1,000 revolutions/minute). Then, discard the supernatant and use DF12-culture medium rinse three times. Add the culture medium to a culture flask.
6. The number of cryopreserved cells should reach $10^{7} / \mathrm{mL}$, and the number of cells should be approximately $5 \times 10^{5} /$ $\mathrm{mL}$ after 1:20 dilution.

\section{OEC quality-control standards Detection of exogenous factors in cell products}

Follow the current version of the Chinese Pharmacopoeia relating to biological products in order to detect any exogenous bacteria, fungi, mycoplasma, and endotoxins.

\section{Cell activity}

Using placental blue staining, cell activity should reach more than $95 \%$.

\section{Cell immunophenotype}

Use p $75^{\mathrm{NGFR}}$ (low-affinity neurotrophic factor receptor) and fibronectin-immunofluorescence staining to identify OECs. The sample should reach a positive rate of $90 \%$.

\section{Tumorigenicity}

According to results of clinical research of allogeneic olfactory-bulb OECs, there should be no tumorigenesis in the tested sample.

\section{Cell-quality control and management}

Cell products must be double-reviewed before use in any clinical transplant treatments. Laboratory personnel are responsible for performing the double quality review and testing, and should sign a standardized form indicating that all checks have been carried out satisfactorily. ${ }^{37}$

\section{Numbers of clinical cells}

Follow guidelines for the use of cells in the application of neurorestorative cell therapy. ${ }^{41,42}$ The number of cells in the provided sample and generation times should be documented.

\section{Temperature and time control during clinical cell transport}

After the cell product is prepared, the temperature of the biosafety transport box should be kept at a constant $4^{\circ} \mathrm{C}$ and the cells transplanted within 2 hours. ${ }^{39,43}$

\section{Management of cell bank}

Files of OEC clinical therapeutic applications and a cellbank management system should be established according to cell sources, number of culture passages, location in 
the liquid-nitrogen tank, date of cryopreservation, human leukocyte-antigen matching, and other relevant details.

\section{Summary}

Formulating common standards for OEC culture and quality control is crucial for the standardization of clinical neurorestorative therapy. Our goal in publishing this set of standards is to promote the worldwide safety, effectiveness, and replicability of utilizing OECs for clinical neurorestorative application. These guidelines represent the minimum required standards of OEC culture and quality control for use in current clinical neurorestorative therapy. These standards will be further optimized and improved in the future according to progress made in preclinical and clinical studies.

\section{Acknowledgment}

We sincerely thank Professor Priscilla Song (Washington University in St Louis) for her editorial assistance in polishing this manuscript.

\section{Disclosure}

The authors report no conflicts of interest in this work.

\section{References}

1. Raisman G. Specialized neuroglial arrangement may explain the capacity of vomeronasal axons to reinnervate central neurons. Neuroscience. $1985 ; 14: 237-254$.

2. Doucette R. Glial influences on axonal growth in the primary olfactory system. Glia. 1990;3:433-449.

3. Doucette R. PNS-CNS transitional zone of the first cranial nerve. J Comp Neurol. 1991;312:451-466.

4. Ramón-Cueteo A, Nieto-Sampedro M. Regeneration into the spinal cord of transected dorsal root axons is promoted by ensheathing glia transplants. Exp Neurol. 1994;127:232-244.

5. Ramón-Cueto A, Valverde F. Olfactory bulb ensheathing glia: a unique cell type with axonal growth-promoting properties. Glia. 1995;14: 163-173.

6. Franklin RJ, Gilson JM, Franceschini IA, Barnett SC. Schwann cell-like myelination following transplantation of an olfactory bulbensheathing cell line into areas of demyelination in the adult CNS. Glia. 1996;17:217-224.

7. Li Y, Field PM, Raisman G. Repair of adult rat corticospinal tract by transplants of olfactory ensheathing cells. Science. 1997;277: 2000-2002.

8. Ramón-Cueto A, Avila J. Olfactory ensheathing glia: properties and function. Brain Res Bull. 1998;46:175-187.

9. Ramón-Cueto A, Plant GW, Avila J, Bunge MB. Long-distance axonal regeneration in the transected adult rat spinal cord is promoted by olfactory ensheathing glia transplants. $J$ Neurosci. 1998;18: 3803-3815.

10. Ramón-Cueto A, Cordero MI, Santos-Benito FF, Avila J. Functional recovery of paraplegic rats and motor axon regeneration in their spinal cords by olfactory ensheathing glia. Neuron. 2000;25:425-435.

11. Franklin RJ. Remyelination by transplanted olfactory ensheathing cells. Anat Rec B New Anat. 2003;271:71-76.

12. Raisman G, Li Y. Repair of neural pathways by olfactory ensheathing cells. Nat Rev Neurosci. 2007;8:312-319.
13. Franssen EH, de Bree FM, Verhaagen J. Olfactory ensheathing glia: their contribution to primary olfactory nervous system regeneration and their regenerative potential following transplantation into the injured spinal cord. Brain Res Rev. 2007;56:236-258.

14. Richter MW, Roskams AJ. Olfactory ensheathing cell transplantation following spinal cord injury: hype or hope? Exp Neurol. 2008;209:353-367.

15. Su Z, He C. Olfactory ensheathing cells: biology in neural development and regeneration. Prog Neurobiol. 2010;92:517-532.

16. Ramón-Cueto A, Muñoz-Quiles C. Clinical application of adult olfactory bulb ensheathing glia for nervous system repair. Exp Neurol. 2011;229:181-194.

17. Higginson JR, Barnett SC. The culture of olfactory ensheathing cells (OECs): a distinct glial cell type. Exp Neurol. 2011;229:2-9.

18. LiY, Chen L, Zhao Y, et al. Intracranial transplant of olfactory ensheathing cells can protect both upper and lower motor neurons in amyotrophic lateral sclerosis. Cell Transplant. 2013;22:S51-S65.

19. Wu W, Hui G, Lu H, Lv R. [Effects of different materials and culture methods on the purity of fetal olfactory ensheathing cells]. Zhonghua Shi Yan Wai Ke Za Zhi. 2004;21:841-844. Chinese.

20. Qian LM, Zhang ZJ, Jiang P. [A novel glia: olfactory ensheathing cell]. Prog Anat Sci. 2006;12:63-66. Chinese.

21. Huang HY. [Basic and clinical study of olfactory ensheathing cell transplantation for spinal cord injury]. Chin J Clin Rehabil. 2002;6:2027-2029. Chinese.

22. Huang HY, Wang HM, Xiu B, et al. Preliminary report of clinical trial for olfactory ensheathing cell transplantation treating the spinal cord injury. J Navy Gen Hosp PLA. 2002;15:18-21. Chinese.

23. Huang HY, Chen L, Wang HM, et al. Influence of patients' age on functional recovery after transplantation of olfactory ensheathing cells into injured spinal cord injury. Chin Med J (Engl). 2003;116:1488-1491.

24. Huang H, Chen L, Xi H, et al. Fetal olfactory ensheathing cells transplantation in amyotrophic lateral sclerosis patients: a controlled pilot study. Clin Transplant. 2008;22:710-718.

25. Mackay-Sim A, Féron F, Cochrane J, et al. Autologous olfactory ensheathing cell transplantation in human paraplegia: a 3-year clinical trial. Brain. 2008;131:2376-2386.

26. Huang HY, Chen L, Xi HT, et al. [Olfactory ensheathing cells transplantation for central nervous system diseases in 1,255 patients]. Zhongguo Xiu Fu Chong Jian Wai Ke Za Zhi. 2009:23:14-20. Chinese.

27. Chen L, Huang H, Xi H, et al. Intracranial transplant of olfactory ensheathing cells in children and adolescents with cerebral palsy: a randomized controlled clinical trial. Cell Transplant. 2010;19:185-191.

28. Huang H, Xi H, Chen L, Zhang F, Liu Y. Long-term outcome of olfactory ensheathing cell therapy for patients with complete chronic spinal cord injury. Cell Transplant. 2012;21:S23-S31.

29. Chen L, Chen D, Xi H, et al. Olfactory ensheathing cell neurorestorotherapy for amyotrophic lateral sclerosis patients: benefits from multiple transplantations. Cell Transplant. 2012;21:S65-S77.

30. Rao Y, Zhu W, Guo Y, et al. Long-term outcome of olfactory ensheathing cell transplantation in six patients with chronic complete spinal cord injury. Cell Transplant. 2013;22:S21-S25.

31. Tabakow P, Jarmundowicz W, Czapiga B, et al. Transplantation of autologous olfactory ensheathing cells in complete human spinal cord injury. Cell Transplant. 2013;22:1591-1612.

32. Chen L, Xi H, Huang H, et al. Multiple cell transplantation based on an intraparenchymal approach for patients with chronic phase stroke. Cell Transplant. 2013;22:S83-S91.

33. Xi H, Chen L, Huang H, et al. Preliminary report of multiple cell therapy for patients with multiple system atrophy. Cell Transplant. 2013;22:S93-S99.

34. Tabakow P, Raisman G, Fortuna W, et al. Functional regeneration of supraspinal connections in a patient with transected spinal cord following transplantation of bulbar olfactory ensheathing cells with peripheral nerve bridging. Cell Transplant. 2014;23:1631-1655.

35. Chen L, Huang H, Xi H, et al. A prospective randomized double-blind clinical trial using a combination of olfactory ensheathing cells and Schwann cells for the treatment of chronic complete spinal cord injuries. Cell Transplant. 2014;23:S35-S44. 
36. Wang S, Lu J, Li YA, et al. Autologous olfactory lamina propria transplantation for chronic spinal cord injury: three-year follow-up outcomes from a prospective double-blinded clinical trial. Cell Transplant. 2016;25:141-157.

37. Ren YS, Huang HY, Chen L, et al. The primary culture for human embryonic olfactory ensheathing cells of olfactory bulb. Prog Anat Sci. 2010;16:97-100. Chinese.

38. Ren YS, Tian GZ, Wang HM, Huang HY, Chen L. Quality specification of human embryo olfactory ensheathing cells from olfactory bulb. J Clin Rehabil Tissue Eng Res. 2008;12:3156-3157. Chinese.

39. Jiang XR, Xiao J, Ren YS, et al. The influence of 4 degree centigrade concervation [sic] on cells activity of rats' olfactory bulbs derived olfactory ensheathing cells. Prog Anat Sci. 2011;17:424-427. Chinese.
40. International Association of Neurorestoratology [homepage on the Internet]. Available from: http://www.ianr.org.cn/zcfg. Accessed September 8, 2017. Chinese.

41. Chinese Medical Association of Neurorestoratology Professional Committee, Chinese Branch of International Association of Neurorestoratology. Chinese clinical application guideline of neurorestorative cell therapy (version 2015). Chin J Cell Stem Cell. 2016;6:1-7. Chinese.

42. Huang H, Chen L, Zou Q, et al. Clinical cell therapy guidelines for neurorestoration (China version 2016). J Neurorestoratol. 2017;5: 39-46.

43. Gobbel GT, Kondziolka D, Fellows-Mayle W, Uram M. Cellular transplantation for the nervous system: impact of time after preparation on cell viability and survival. J Neurosurg. 2010;113:666-672.
Journal of Neurorestoratology

\section{Publish your work in this journal}

The Journal of Neurorestoratology is an international, peer-reviewed, open access online journal publishing original research and review articles on the subject of Neurorestoratology. To provide complete coverage of this revolutionary field the Journal of Neurorestoratology will report on relevant experimental research, technological advances,

\section{Dovepress}

and clinical achievements. The manuscript management system is completely online and includes a very quick and fair peer-review system, which is all easy to use. Visit http://www.dovepress.com/testimonials. php to read real quotes from published authors. 